\title{
Analysis of Individual Characteristics, Transmigration Aspects and Transmigrant Employment Structures (Study in ex-Transmigration Villages within Jambi Province)
}

\section{Yulmardi ${ }^{1}$, Erfit $^{2}$}

${ }^{1}$ FEB, University of Jambi, Jambi and Indonesia, $\square$ (e-mail) yulmardiedy@yahoo.co.id

${ }^{2} \mathrm{FEB}$, University of Jambi, Jambi and Indonesia, $\square$ (e-mail) erfitibrahim@yahoo.com

\begin{abstract}
This study aims to analyze the individual characteristics of transmigrants in extransmigration villages within Jambi Province, analyze aspects of transmigrant transmigration in the former transmigration villages within Jambi Province, and analyze employment in ex-transmigration villages within Jambi Province. This study was designed by collecting primary data. Research location in 6 (six) sample villages in 3 (three) Districts in three districts in Jambi Province. The research instrument used questionnaires to interview 168 households as respondents. Sampling by using Random Number Generated (RNG). The method of analysis used is descriptive quantitative and quantitative descriptive.The results found : 1) Average age of family head 64,31 years old. As many as $70.51 \%$ of those interviewed did not have a job. The largest part of the family head is male. Elementary education level/ equal to 45,76 percent. 2) The province's biggest origin is Central Java. Percentage of General Transmigration (88.10\%). The main reason for joining transmigration is for the better future. The arrival of the origin is a direct transmigration. Number of household members carried between 3-4 people. 3) The land mastery of $2.45 \mathrm{Ha}$. Field of business is the most widely occupied agricultural sector (92.95\%), and most as a rough worker. Research suggests that in the welfare context it is necessary to provide training for transmigrant in the field of skills, and the government should make alternatives to the future not dependent on existing land and they are not trapped only in the agricultural sector to anticipate the future, so as to increase the use of land towards a more productive. 2) Research on transmigration should be continued with regard to welfare, especially for more micro-scale studies at the household level.
\end{abstract}

Keywords: transmigration, transmigrant, welfare

\section{Introduction}

Transmigration is one form of migration that takes place in Indonesia. Implementation of the transmigration program has been going on for quite some time, starting in the days of the Dutch colonial government, under the name of colonization until the time of reform at this time. During the reign of the Dutch East Indies (1905-1941) its main objective was to reduce the population density of Java Island, as well as to meet the labor needs in the outer regions of Java Island. Furthermore, during the Japanese government (1942-1945), transmigration was more directed to forcibly displacing people from Java to other Indonesian islands for forced labor for Japanese purposes (Swasono and Singarimbun 1986, Junaidi, 2012).

The development of transmigration has succeeded in creating employment opportunities, equitable distribution of development in the regions, and establishing new growth centers. Based on data center of transmigration information (2012), since Pre Pelita until 2011, has opened 4,537,034 hectares of new agricultural land as a field of business for 2.3 million families resettled or about 8.8 million people. The types of businesses that are created such as trade, services and home industries also grow in line with the growth of agricultural production in transmigration settlements. 
Success achieved in the destination area, also contributed in the area of origin. According to Affandi, J (1985), the role of the originator's thrust is large enough for transmigrants to make decisions for transmigration. Economic factors in the form of narrow land ownership, limited employment, and low income in rural areas make prospective transmigration residents willing to leave their hometown to obtain higher welfare. In addition, the program has also supported the development of several strategic infrastructures in Java.

Jambi Province is one of the transmigration placement areas in Indonesia. The placement of transmigration in this area had begun before independence in 1940, and continues to this day. Based on data from sosial services, employment and transmigration (2016), the number of transmigrants that have been placed in Jambi Province reached 83,641 householder or (355.221inhabitant), with the number positioning Jambi Province as one of the main areas of placement of transmigrants in Indonesia.

At the beginning the placement of transmigrants was provided by the government with an average land allotment of $2 \mathrm{Ha}$ each per householder. There are 2 types of land they receive, with an average family member number of 3-4 people. The first land is located around the house that has been provided (yard) this land planted with short-lived plants such as corn, yam, peanut, and soybean. For the second land is planted with long-lived perennials. The land is used for transmigration not only for agriculture, but also for plantations such as rubber and oil palm. The area of transmigration Rimbo Bujang rubber plant is one of the most widely planted commodities by transmigrants and also the surrounding community because it quickly brings benefits.

In the long journey of transmigration in Jambi Province, it has demonstrated various successes from demography, socio-cultural and economic aspects. However, there are still among transmigration settlements that have failed such as in the tidal transmigration sites in Tanjung Jabung East. Overall percentages that do not work are small. The transmigrants are scattered in almost every district in Jambi Province. Generally they cultivate agricultural products and plantations, such as in Tebo district with rubber plantations, Muaro Jambi seeks palm oil plantations and Tanjung Jabung West and East Timor food crops (rice). The resettlement program is not only meant to make a geographic shift or place of movement, but it is part of a national development plan. Population movements are then directed to more specific economic objectives, which are linked to the development of origin and destination areas. It is no exaggeration to say that transmigration in its selection emphasizes social and humanitarian considerations rather than economic efficiency objectives.

Various empirical phenomena according to Junaidi (2012), shows the inequality of prolonged development ultimately lead to counter-productive effects on various efforts that have been done for the growth of growth itself. In countries with high economic growth rates, the sustainability of growth can be maintained by a level of uneven progress. Unlike the case with developing countries where high economic progress is often followed by inequality in inter-regional economic development. This condition cannot be separated from the existence of the weakest components. This means that the level of progress achieved by the region is also determined by the condition of the disadvantaged areas that exist.

In relation to the transfebility of migrant skills disclosed by Bazzi, S et.al (2016) We use natural experiment in Indonesia to provide the causal evidence on the role of location -specipic human capital and skill of transfusion in shaping the spatial distribution of productivity from 1979-1988, the transmigration program located two million migrants from rural Java and Bali to the new rural settlements in the outer islands. Given the transmigration implementation in Jambi Province has been running for quite a long time, so it needs to be studied how the development has been achieved by transmigrants. These aspects include socio-economic development, migration profile, and employment structure of transmigrants in ex-transmigration villages within Jambi Province. 


\section{Methods}

\section{Population and Sampling}

In this study the population is determined by stages. The first stage is determined by the population of all transmigrant family heads who have lived in the location for more than 20 years or have had a derivative (second generation). The second phase of the target population is transmigration households with second generation who are over 20 years old or who have married status, both still in ex villages. Transmigration is transmigration settlement units that have become definitive villages or those who no longer reside with their parents (first generation) and have formed a new family (second generation). In addition to the reasons already stated, the number of samples is also highly dependent other factors such as costs, facilities, available time, existing or willing populations to be sampled, and the objectives and analytical tools used.

Furthermore, in the determination of representative samples is used random sampling (random sampling). What is meant by random (random) is that every member of the population has equal opportunity to be included as a sample. Thus it will be studied as many as 168 respondents from 6 (six) villages spread over three districts in Jambi Province.

\section{Data Sources}

In this study required data, both sourced from primary and secondary data. Primary data were obtained directly at the sample household level collected using a questionnaire instrument. The questionnaire is a set of specific questionnaires that are organized in a systematic and complete. It also used structured interviews. In certain cases, interviews were also conducted on several key informants who were considered to know about the issues related to transmigration research. The types of primary data collected from first generation respondents include social, economic, transmigration, and labor structure characteristics. Secondary data is obtained from related institutions.

\section{Method of Analysis}

To answer the research objectives that have been stated previously: the characteristics and socioeconomic conditions of transmigrants, analyzed on individual data. The aspects of transmigration referred to in this study include the characteristics of the head of the family, the structure and activities of family members, the province of origin, the reasons for joining transmigration. Number of ART brought. Employment includes current main activities, business field, occupation type, employment status, side job ownership and working hours per week. The analysis was done descriptively by using frequency table and cross table and compile the condition in each sub district of selected location.

\section{Results}

\section{Transmigrant Individual Characteristics}

\section{Age of Family Head}

The average age of respondent household heads in transmigration areas in Jambi Province varies, with an average age of 64.31 years. By age group, it can be explained that the majority of family heads $(63.10 \%)$ are in the age of 60 years and above. This condition shows that only about $36.90 \%$ of household heads are still in productive age.

\section{Gender}

Most (79.76\%) of the head of household are male, and the remaining 20.24 percent are women. Based on the sample area, the head of female family for Rimbo Bujang is higher than Batang Asam and Sungai Bahar. This situation in Rimbo Bujang Head of the female family as much as 44.64 percent, Bahar River 16.07\% and no head of household in Batang Asam with the status of women. 


\section{Education}

Most of the respondents in the research area (42.86\%) have primary school education (SD). Respondents who have not / have not attended school and who have not / have not completed primary school $(33.92 \%)$. With a low education will certainly affect the decision-making process. For respondents with junior high school education and vocational education amounted to 13.09 percent. Meanwhile, the number of senior high school education is as much $(8.93 \%)$, and only $1.19 \%$ percent of respondents are graduated from Diploma IV / Bachelor Degree. The circumstances of respondents based on the level of education that can be rescued are presented in detail in Table 1. below.

Table 1 Percentage of respondents by education arrested at transmigration sites of Jambi Province, Year 2017

\begin{tabular}{|c|c|c|c|c|}
\hline \multirow[b]{2}{*}{ Transmigrant Education } & \multicolumn{3}{|c|}{ Districts } & \multirow[b]{2}{*}{ Total } \\
\hline & $\begin{array}{l}\text { Rimbo } \\
\text { Bujang }\end{array}$ & $\begin{array}{c}\text { Batang } \\
\text { Asam }\end{array}$ & $\begin{array}{c}\text { Sungai } \\
\text { Bahar }\end{array}$ & \\
\hline \multirow[t]{2}{*}{ No School Ever } & 16 & 0 & 0 & 16 \\
\hline & $(28,57)$ & $(0,00)$ & $(0,00)$ & $(9,52)$ \\
\hline \multirow[t]{2}{*}{ No / Not yet Graduated Elementary School } & 22 & 13 & 6 & 41 \\
\hline & $(39,29)$ & $(23,21)$ & $(10,71)$ & $(24,40)$ \\
\hline \multirow[t]{2}{*}{ Elementary School } & 16 & 36 & 20 & 72 \\
\hline & $(28,57)$ & $(64,29)$ & $(35,71)$ & $(42,86)$ \\
\hline \multirow[t]{2}{*}{ Junior High School } & 0 & 5 & 13 & 18 \\
\hline & $(0,00)$ & $(8,93)$ & $(23,21)$ & $(10,71)$ \\
\hline \multirow[t]{2}{*}{ Junior High School } & 1 & 0 & 3 & 4 \\
\hline & $(1,79)$ & $(0,00)$ & $(5,36)$ & $(2,38)$ \\
\hline \multirow[t]{2}{*}{ Senior High School } & 1 & 2 & 12 & 15 \\
\hline & $(1,79)$ & $(3,57)$ & $(21,43)$ & $(8,93)$ \\
\hline \multirow[t]{2}{*}{ Diploma IV/ Bachelor Degree } & 0 & 0 & 2 & 2 \\
\hline & $(0,00)$ & $(0,00)$ & $(3,57)$ & $(1,19)$ \\
\hline \multirow[t]{2}{*}{ Total } & 56 & 56 & 56 & 168 \\
\hline & $(100,00)$ & $(100,00)$ & $(100,00)$ & $(100,00)$ \\
\hline
\end{tabular}

Source : Research, 2017

\section{Aspects of Transmigration Transmigrant}

\section{Province of Origin}

In general, the province of origin of transmigration originated from the provinces of Java. According to the results of the study, the number of transmigrants was 88.69 percent dominated by East Java (39.29\%), Yogjakarta (21.43\%), West Java (16.07\%) and East Java (11.90\%). For those who come from outside the island of Java the number is not too many are incoming migrants from the Province on the island of Sumatra. The number of consecutive arrivals in Jambi Province (also called translok), followed by Lampung Province (2.38\%), North Sumatra $(1.79 \%)$ and West Sumatera and South Sumatra respectively $0.60 \%$.

\section{Year Early Stay in The Village}

The placement of transmigration can be distinguished for Rimbo Bujang being transmigrants placed in periods (1975-1977), in Batang Asam period (1986-1988) and period (1991-1994) for the location of the Bahar River. Based on the placement year it is estimated that at Rimbo Bujang location the transmigrants have been living for more than 41 years, in Batang Asam about 30 years and 25 years for the location of Bahar River. Based on the duration of living in the transmigration area, the descendants have already entered the second generation, even to the third. 


\section{Transmigration Status}

In most research sites $(88.10 \%)$ of transmigrants are general transmigrants, while swakarsa transmigration amounts to 9.52 percent, and only about 2.38 percent are spontaneous. Based on the sample area it was found that in Rimbo Bujang the number of swakarsa transmigrants $(25.00 \%)$, for Batang Asam (3.57\%) and no swakarsa transmigration on the Bahar River.

\section{Reasons for Transmigration}

The reasons are landless, forced to move due to dam construction, no jobs, better future, and family participation. Most respondents (68.45\%) for reasons of a better future, is higher in the Bahar River location as much (94.64\%), compared to Batang Asam, or Rimbo Bujang. Around 18.45 percent of transmigrants leave their home areas because they have no land to work on, this factor encourages them to move. Transmigrants who participated in the program that are not having a job, accounted as much as 6.55 percent. Only a small proportion of transmigrants $(2.98 \%)$ leave their home areas with the excuse of joining the family.

Table 2 Percentage of respondents according to reasons to participate in transmigration at the transmigration site in Jambi Province, Year 2017

\begin{tabular}{|c|c|c|c|c|}
\hline \multirow[b]{2}{*}{ Reasons for Transmigration } & \multicolumn{3}{|c|}{ Districts } & \multirow[b]{2}{*}{ Total } \\
\hline & $\begin{array}{l}\text { Rimbo } \\
\text { Bujang }\end{array}$ & $\begin{array}{c}\text { Batang } \\
\text { Asam }\end{array}$ & $\begin{array}{l}\text { Sungai } \\
\text { Bahar }\end{array}$ & \\
\hline \multirow[t]{2}{*}{ Has no land } & 20 & 11 & 0 & 31 \\
\hline & $(35,71)$ & $(19,64)$ & $(0,00)$ & $(18,45)$ \\
\hline \multirow[t]{2}{*}{ Forced to move because of dam construction } & 6 & 0 & 0 & 6 \\
\hline & $(10,71)$ & $(0,00)$ & $(0,00)$ & $(3,57)$ \\
\hline \multirow[t]{2}{*}{ Do not have a job } & 1 & 9 & 1 & 11 \\
\hline & $(1,79)$ & $(16,07)$ & $(1,79)$ & $(6,55)$ \\
\hline \multirow[t]{2}{*}{ For the future better } & 28 & 34 & 53 & 115 \\
\hline & $(50,00)$ & $(60,71)$ & $(94,64)$ & $(68,45)$ \\
\hline \multirow[t]{2}{*}{ Join the family } & 1 & 2 & 2 & 5 \\
\hline & $(1,79)$ & $(3,57)$ & $(3,57)$ & $(2,98)$ \\
\hline \multirow[t]{2}{*}{ Total } & 56 & 56 & 56 & 168 \\
\hline & $(100,00)$ & $(100,00)$ & $(100,00)$ & $(100,00)$ \\
\hline
\end{tabular}

Source : Research, 2017

\section{Arrival from Origin}

Most of the transmigrants in Jambi Province in the study area $(88.10 \%)$ were transmigrants who moved directly. The remaining approximately (11.90\%) is a transmigration that has made no movement from the origin but from the previous place of movement. The high level of displacement that occurs between the first destination area with the next area is greatly influenced by many factors. The causes can be social, economic, cultural, security, natural disaster and so on (Tukiran, 2002).

\section{Number of Household Members Taken}

The total number of household members who were taken when transmigrating on average is (3.31 people). Based on the study sites, the average ART in Rimbo Bujang was 3.66 people, higher than the average of ART in Batang Asam (3.57 people) and the Bahar River was only (2.70 people). More than half $(55.95 \%)$ of the transmigrants in the study area when they started out of their home areas had ART levels ranging from 3-4 people. There were as many as $30.36 \%$ of the transmigrant households' heads when leaving their home areas with those with ART between 1-2 people, and only about $13.69 \%$ of the transmigrants departing from their home areas with ART greater than 4 


\section{Transmigrant Employment}

\section{Transmigrant Employment Current Main Activities}

Almost all households (92.86\%) had primary activity at this time "Working", and only a small portion of $(7.14 \%)$ were recipients of income. The head of the household who is recorded as the recipient of this income is either due to unproductive due to old age, and the land is cultivated by others and there is also a reason prohibited by their children who already have better income.

\section{Business Field}

Almost two-thirds $(65.38 \%)$ of respondents at transmigration sites work in the plantation sector. Then food crop agriculture is the second sector of business field of the respondents with the number of $(26.92 \%)$. Other service sectors recorded as many as $(3.21 \%)$. The concentration of the first generation business field in Plantation and Food Crops Sector $(92.30 \%)$ cannot be denied because the existing transmigration form in Jambi Province is General Transmigration (TU) of $88.10 \%$. As is known transmigration pattern is all the burden of costs that appear to be dependent government included in the preparation of land. The development of non plantation and food crops sector at transmigrant sites is still relatively limited.

\section{Type of Work}

Most of the first generation, (81.41\%) work as agricultural and livestock farmers. Then, it is followed by the type of work as Crude workers, cleaning personnel and energy as much $(12.18 \%)$. The rest of the first generation in the research area, work as professionals (2.56\%), and service business and sales business (2.56\%), and only about $1.28 \%$ as Administrative Staff.

\section{Job Status}

Peke status most respondents $(70.51 \%)$ are self-employed. This means that the first generation of transmigration in the research location does not work on the other side. They are farmers who work in their own land and are independent of others, and are included in the process of producing and marketing the results. The decision taken is usually determined not through consultation with other parties but the final decision is an individual decision, which is a distinctive feature of the status of self-employment work. Respondents with employment status, working with unpaid family workers is accounted for $(13.46 \%)$. This means that the involvement of families in carrying out the work is meaningful even though the economic contribution of the family is less calculated. The role of family members participates in sustaining the household economy in the form of actively participating in out-of-home activities in the production of goods and services. More detailed conditions are presented in Table 3.

Table 3 Percentage of Respondents According to Employment Status at Transmigration Sites

\begin{tabular}{lrrrr}
\hline \multirow{2}{*}{ Job Status Transmigrant } & \multicolumn{3}{c}{ District } & \multirow{2}{*}{ Total } \\
\cline { 2 - 5 } & Rimbo Bujang & Batang Asam & Sungai Bahar & \\
\hline Trying to Own & 25 & 51 & 34 & 110 \\
\hline Trying with family workers / not paying & $(56,82)$ & $(91,07)$ & $(60,71)$ & $(70,51)$ \\
\cline { 2 - 5 } & 5 & 3 & 13 & 21 \\
\hline Trying to keep workers & $(11,36)$ & $(5,36)$ & $(23,21)$ & $(13,46)$ \\
\cline { 2 - 5 } & 7 & 0 & 3 & 10 \\
\hline Labor / Employee & $(15,91)$ & $(0,00)$ & $(5,36)$ & $(6,41)$ \\
\cline { 2 - 5 } & 7 & 2 & 6 & 15 \\
\hline \multicolumn{1}{c}{ Total } & $(15,91)$ & $(3,57)$ & $(10,71)$ & $(9,62)$ \\
\cline { 2 - 5 } & & 54 & 56 & 156 \\
\hline
\end{tabular}

Source : Research, 2017 


\section{Ownership of Side Jobs}

Overall the respondents who have side jobs amounted to (29.49\%). The rest of the respondents (70.51\%) have no side jobs. Based on the location of the sub district, the respondent's variations have side jobs and no side jobs are not too significant. The large number of respondents who do not have a side job means their focus is more focused on the main job. This also means that the main source of household income of respondents comes from the main work. Thus the outpouring of time allocated to obtain production is largely for basic work.

\section{Working Hours per Week}

The average working hours per week of respondents amounted to ( 31.54 hours) in a week. When compared to normal working hours according to International Labor Organization (ILO) standards for 35 hours or more, transmigrant work hours are still under or under full working hours. Overall, those working within a week 35 hours or more less than half $(48.72 \%)$. There are 31.41 percent who have working hours between (14-34 hours) per week. In other parts there are still those who devote less than 14 hours per week.

\section{Conclusions}

The results showed the average age of the head of the family (first generation) at the transmigration site of Jambi Province for 64.31 years. With that age the respondents included in the unproductive age group, this is indicated by $70.51 \%$ of those interviewed have no job. The largest part of the head of the family is male. The greatest part of education level is SD / equal to 45.76 percent. The percentage of first generation based on the province's largest origin is Central Java. The percentage of first generation according to transmigration status is General Transmigration $(88,10 \%)$. The main reason for joining transmigration is for the better future. The arrival of the regions of origin is largely a direct transmigration. The number of household members brought from the area of origin numbered between 3-4 people. Land acquisition by the first generation is still high and their dependence on land outside the transmigration area is low. The number of first generation who have fewer side jobs than the second generation. The business field that is mostly occupied by the first generation is in the agricultural sector of 92.95 percents. Of the first-generation type of work, the most abundant are crude workers.

\section{References}

Alatas, S. (1995). Studi Migrasi Penduduk Indonesia. Dalam Migrasi dan Distribusi Penduduk di Indonesia. Kantor Menteri Negara Kependudukan/BKKBN: Jakarta.

Amri, A., Junaidi, and Yulmardi. (2009). Metodologi Penelitian Ekonomi Dan Penerapannya. IPB PRESS: Bogor.

Badan Pusat Statistik Provinsi Jambi. (2015). Jambi Dalam Angka 2015. Jambi.

Badan Pusat Statistik Provinsi Jambi. (2016). Jambi Dalam Angka 2016. Jambi.

Everret, S,L. (1966). A Theory of Migration dalam Demgraphy (suatu Teori Migasi) Pusat Penelitian Kependudukan. Vol 3. Universitas Gadjah Mada. Yogjakarta.

Fearnside.P.M. (1997). Transmigration in indonesia: lessons from its environmental and social impact. Emviromental management. 21(4).

Junaidi dan Hardiani. (2009). Dasar-Dasar Teori Ekonomi Kependudukan. Hamada Prima: Bogor.

Junaidi, R., Slamet, J. (2012). Pengembangan penyelenggaraan transmigrasi di era otonomi daerah, Jurnal Visi Publik, 9(1). September 2012.

Junaidi .(2012). Perkembangan desa-desa eks transmigrasi dan interaksi dengan wilayah sekitarnya serta kebijakan ke depan (kajian di provinsi jambi), Disertasi, Sekolah Pasca Sarjana, Institut Pertanian Bogor.

Kemenakertrans. (2011). UPT Menjadi Pusat Pemerintahan 2010. Pusdatin Kemenakertrans: Jakarta.

Mc, Gee. (1976). An analysis of the determinants of internal labour mobility in India, in Annual of regional Science 5. 
Naim, M. (2013). Merantau Pola Migrasi Suku Minangkabau, Edisi Ketiga, Divisi Buku Perguruan Tinggi, PT Raja Grafindo Persada: Jakarta.

[Pusdatin Trans, IPB] Pusat Data dan Informasi Transmigrasi, Institut Pertanian Bogor. 2012. Pengkajian Informasi dan Analisis Tingkat Perkembangan UPT dan Tingkat Kesejahteraan Transmigrasi. Jakarta : Pusdatin Transmigrasi.

Republik Indonesia. (1958). Peraturan Pemerintah No. 56 Tahun 1958 tentang Pokok-Pokok Penyelenggaraan Transmigrasi. Jakarta: Sekretaris Negara.

Republik Indonesia (1959). Peraturan Pemerintah No. 13 Tahun 1959 tentang Pokok-Pokok Penyelenggaraan Transmigrasi. Jakarta: Sekretariat Negara.

Republik Indonesia (1960). Peraturan Pemerintah Pengganti Undang-Undang No. 29 Tahun 1960 tentang Pokok-Pokok Penyelenggaraan Transmigrasi.

Republik Indonesia (1965). Peraturan Presiden No. 5 Tahun 1965 tentang Gerakan Nasional Transmigrasi. Jakarta: Sekretariat Negara.

Republik Indonesia. (1972). Undang-Undang No. 3 Tahun 1972 tentang Ketentuan Ketentuan Pokok Transmigrasi. Jakarta: Sekretariat Negara.

Republik Indonesia. Peraturan Pemerintah No. 2 Tahun 199 tentang Lingkup Geografis Kawasan Transmigrasi. Jakarta: Sekretariat Negara.

Republik Indonesia. (2004). Undang-Undang No. 32 Tahun 2004. Tentang Pemerintahan Daerah. Jakarta. Sekretariat Negara.

Republik Indonesia. (2009). Undang-Undang No. 29 Tahun 2009 tentang Perubahan Atas UndangUndang No. 15 Tahun 1997 tentang Ketransmigrasian. Jakarta: Sekretariat Negara.

Republik Indonesia. (2014). Peraturan Pemerintah No. 3 Tahun 2014. Tentang Pelaksanaan UndangUndang No.15 Tahun 1997 tentang Ketransmigrasian Sebagaimana telah diubah dengan UndangUndang No. 29 Tahun 2009 Tentang Ketransmigrasian. Jakarta. Sekretariat Negara.

Swasono dan Singarimbun. (1986). Sepuluh Windu Transmigrasi Di Indonesia 1905- 1985. Penerbit Universitas Indonesia: Jakarta.

Soegiarto S,S., Warsono, H.S. Bustani, N,. (2005). Berbagai Model Pemukiman kembali. Studi Perbandingan Beberapa Negara. Pustaka Sinar Harapan: Jakarta.

Tukiran. (2002). Mobilitas Penduduk Indonesia. Tinjauan Lintas Disiplin. Pusat Studi Kependudukan dan Kebijakan. UGM: Yogjakarta.

Warsono, S. H. (2012). Transmigrasi, perpindahan penduduk dan disparitas ekonomi wilayah. Jurnal Visi Publik.September 2012.

Yulmardi, (2008). Makalah mobilitas penduduk. Pelatihan (PPD). Kerjasama Fakultas Ekonomi Universitas Jambi dengan Pemerintah Daerah Kabupaten Sarolangun. Tahun 2008. 